\title{
Peran bentuk social support terhadap academic burnout pada mahasiswa Psikologi di Universitas " $X$ " Bandung
}

\author{
Lie Fun Fun ${ }^{(1)}$, Ida Ayu Nyoman Kartikawati( ${ }^{(2)}$, Lisa Imelia ${ }^{(3)}$, Fransiska Silvia ${ }^{(4)}$ \\ (1),(2),(3),(4) Fakultas Psikologi, Universitas Kristen Maranatha, Bandung, Indonesia
}

Psychology students may experience the symptoms of academic burnout, which can be reduced by good social supports that may manifest in multifarious forms, be they appraisal, belonging, and tangible. This study aimed to examine the role of social supports in explaining academic burnout among psychology undergraduate students. Participants were 327 psychology undergraduate students at X University who were recruited based on quota sampling. We analysed the data using multiple regression analysis to assess how much social supports contribute to academic burnout. The results revealed that belonging (15\%) and appraisal (12\%) significantly contributed, whereas tangible did not contribute to participants' symptoms of academic burnout. These observations, overall, suggest the importance of conducting follow-up research using qualitative methods and involving other factors beyond social supports that arguably affect academic burnout among psychology students.

\section{Keywords: academic burnout, psychology students, social support}

Mahasiswa psikologi memiliki peluang yang besar untuk mengalami gejala academic burnout, yang bisa dikurangi melalui dukungan sosial berupa appraisal, belonging dan tangible. Penelitian ini bertujuan untuk mendapatkan gambaran tentang peran bentuk dukungan sosial terhadap burnout academic pada mahasiswa program studi sarjana psikologi. Sebanyak 327 mahasiswa psikologi di Universitas " $\mathrm{X}$ " dipilih menggunakan sampling kuota. Data dianalisis menggunakan regresi berganda. Hasil penelitian menunjukkan bahwa bentuk dukungan sosial yang paling berkontribusi terhadap gejala burnout academic yang dialami partisipan adalah belonging (15\%) dan appraisal (12\%), sementara tangible support tidak berkontribusi secara signifikan. Temuan ini menekankan pentingnya dilakukan penelitian lanjutan dengan menggunakan metode kualitatif serta melibatkan faktor-faktor selain dukungan sosial yang secara logis mempengaruhi academic burnout pada mahasiswa psikologi.

Kata kunci: academic burnout, dukungan sosial, mahasiswa psikologi

MEDIAPSI, 2021, Vol. 7(1), 17-26, DOI: https://doi.org/10.21776/ub.mps.2021.007.01.3

Received: 04-02-2020. Revised: 02-10-2020. Accepted: 07-11-2020. Published online: 24-06-2021 Handling Editor: Sumi Lestari, Universitas Brawijaya, Malang, Indonesia

*Corresponding author: Lie Fun Fun Fakultas Psikologi, Universitas Kristen Maranatha, Bandung, Indonesia. E-mail: lie.ff@psy.maranatha.edu

This work is licensed under a Creative Commons Attribution-NonCommercial 4.0 International License.

How to cite this article in accordance with the American Psychological Association (APA) $7^{\text {th }}$ guidelines:

Fun, L. F., Kartikawati, I. A. N., Imelia, L., \& Silvia, F. (2021). Peran bentuk social support terhadap academic burnout pada mahasiswa Psikologi di Universitas "X" Bandung. MEDIAPSI, 7(1), 17-26. https://doi.org/10.21776/ub.mps.2021.007.01.3

\section{Pendahuluan}

Studi di jurusan psikologi memiliki keunikan tersendiri yang berbeda dari jurusan lain. Mahasiswa yang mengikuti proses pembelajaran di jurusan psikologi dididik untuk memahami perilaku manusia 
melalui kegiatan belajar di kelas, melakukan kegiatan praktikum berupa pengambilan data dengan cara melakukan wawacara, observasi, pemberian tes serta pembuatan laporan singkat tentang individu tersebut. Kegiatan praktikum ini menuntut interaksi yang cukup mendalam dengan individu lain. Sebagai konsekuensinya, mahasiswa dituntut untuk mampu mengenali diri sendiri, memiliki empati yang tepat pada orang lain, serta mampu melakukan analisa terhadap kasus dengan berbagai teori psikologi. Proses pembelajaran di jurusan psikologi sendiri berlangsung selama delapan semester atau empat tahun dan diakhiri dengan pembuatan penelitian atau skripsi sesuai dengan minat mahasiswa.

Menurut Cole dkk. (2004), mengikuti perkuliahan di perguruan tinggi itu adalah situasi yang stressful. Menurut Bedewy dan Gabriel (2015) terdapat beberapa faktor yang menyebabkan mahasiswa mengalami stres akademik, yaitu persepsi akan beban studi yang banyak, tugas perkuliahan yang berlebihan, kurangnya fasilitas atau sarana prasarana untuk belajar, soal ujian yang terlalu sulit, waktu ujian yang singkat turut menjadi sumber stres bagi mahasiswa, termasuk tuntutan dan harapan akan prestasi akademik yang berlebihan dari orangtua atau pengajar, persaingan teman sebaya, kecemasan, rasa takut gagal, dan ketidakpastian akan masa depan. Keadaan stres tersebut dapat memengaruhi produktivitas atau membuat proses belajar individu cenderung lebih sulit, sehingga keadaan yang stress memerlukan kemampuan coping (Cole dkk., 2004).

Sejumlah peneliti telah menemukan bahwa siswa yang mengalami stres akan cenderung menunjukkan kemampuan akademik yang menurun (Rafidah dkk., 2009), kesehatan yang memburuk (Chambel
\& Curral, 2005; Marshall dkk., 2008), depresi (Das \& Sahoo, 2012; Jayanthi dkk., 2015), dan gangguan tidur (Waqas dkk., 2014). Jika stress terjadi terus-menerus tanpa ada yang tertangani dan kronis bisa mengarah pada terjadinya burnout (Baron \& Greenberg, 2008 ).

Burnout merupakan suatu sindrom yang banyak ditemui pada profesi sebagai helping relationship; seperti: dokter, perawat, psikolog, guru (Maslach dkk., 2004; Yang, 2004). Namun demikian seiring dengan perkembangan burnout, ditemukan bahwa sindrom ini juga ditemukan pada pelajar (Yang, 2004). Penelitian yang dilakukan oleh Jimenez-Ortiz dkk. (2019), sebanyak $52 \%$ mahasiswa mengalami burnout pada saat menjalankan proses studi. Penelitian Almeida dkk. (2016) menyatakan bahwa sebanyak $15 \%$ mahasiswa kedokteran mengalami burnout dan sebanyak 58\% terindikasi mengalami gejala mengarah pada kondisi burnout. Hal yang senada diungkapkan dalam penelitian yang dilakukan oleh Sutoyo dkk. (2018) bahwa sebanyak $44 \%$ dari residen bagian anestesiologi di Universitas Padjajaran mengalami gejala burnout yang tinggi.

Burnout ditandai dengan tiga aspek yang penting, yaitu kelelahan secara emosional atau emotional exhaustion karena tuntutan studi, sikap sinis atau depersonalisasi dalam mengikuti perkuliahan dan perasaaan tidak kompeten atau lack of personal accomplishment dalam menilai diri sendiri (Schaufelli, 2002). Mahasiswa mengalami kebosanan yang kuat dalam mengikuti proses belajar, motivasi belajar menurun sampai akhirnya memunculkan penghayatan bahwa dirinya tidak akan mampu menyelesaikan proses studi. Kebosanan ini muncul dalam bentuk melakukan penundaan tugas, kualitas belajar 
tidak optimal, serta tidak konsentrasi dalam menyelesaikan tugas yang berakibat pada prestasi akademik menurun dan waktu kelulusan bertambah panjang.

Burnout yang dialami pelajar dikenal dengan istilah academic burnout yang berdampak pada menurunnya academic performance, memunculkan sikap negatif terhadap universitas, dan munculnya perasaan tidak efisien (Schaufeli dkk., 2002). Kondisi academic burnout memberikan dampak yang buruk terhadap performa akademik (Lin \& Huang, 2014). Studi dari Burr dan Dallaghan (2019) yang dilakukan pada mahasiswa Fakultas Kedokteran di Amerika Serikat menyatakan bahwa ada keterkaitan antara academic burnout, khususnya pada dimensi professional efficacy dengan academic performance. Penelitian yang dilakukan oleh Rana (2016) terhadap mahasiswa teknik informatika di Universitas Islam Bahwalpur menunjukkan bahwa dengan meningkatnya derajat burnout dalam diri mahasiswa maka akan menurunkan kemampuan belajar dan performansi akademik mereka. Pada mahasiswa Bimbingan dan Konseling (BK) di salah satu universitas di Padang mengalami burnout akibat dari standar kompetensi yang harus dicapai (Khairani \& Ifdil, 2015). Dalam proses pembelajaran psikologi pada program magister psikologi ditemukan juga burnout pada mahasiswa yang menjalaninya.

Melihat dampak negatif yang ditimbulkan oleh academic burnout maka perlu dilakukan upaya untuk menguranginya. Salah satu upaya yang dilakukan dengan memberikan dukungan sosial. Salah satu perspektif untuk menjelaskan tentang burnout adalah melalui pendekatan individual, dengan memperhatikan kepribadian, dukungan sosial, dan nilai-nilai yang dianut (Maslach, 2003; Schaufeli, 2002). Menurut Gold dan Roth (1993), salah satu penyebab burnout adalah kurangnya dukungan sosial. Penelitian yang dilakukan oleh Purba dkk. (2007) pada guru didapatkan hasil bahwa semakin besar dukungan sosial yang diterima oleh guru dapat mengurangi derajat burnout. Penelitian oleh Putri (2014) pada perawat rumah sakit di Bogor mendapatkan hasil bahwa kontribusi dukungan sosial sebesar $82 \%$ terhadap burnout, yang berarti dukungan sosial memberikan pengaruh yang kuat dalam menghadapi burnout. Penelitian yang dilakukan oleh Kim dkk. (2017) menyatakan bahwa ada hubungan negatif yang signifikan antara dukungan sosial dengan burnout. Dukungan sosial yang diberikan oleh orangtua dan teman sebaya dapat menurunkan derajat burnout, secara spesifik pada dimensi ketiga (kehilangan tujuan dalam mencapai apa yang dicitacitakan). Sejauh ini, cukup banyak penelitian mengenai dukungan sosial lebih diarahkan pada hubungannya dengan burnout, dengan hasil signifikan negatif serta bentuk dukungan sosial yang diberikan oleh orangtua dan sekolah. Penelitian ini akan mengkaji bentuk dukungan sosial lainnya menurut Cohen dkk. (2000) pada mahasiswa.

Dukungan sosial adalah pertolongan yang diperoleh seseorang dari interaksinya dengan orang lain melalui proses persepsi oleh penerima dukungan tersebut. Menurut Cohen dan Hoberman (dalam Cohen dkk., 2000) dukungan tersebut dapat berupa informasi (appraisal support), keterlibatan (belonging support), dan material (tangible support). Penelitian ini bertujuan untuk mengukur bagaimana peran ketiga bentuk dukungan sosial terhadap academic burnout dan bentuk dukungan sosial yang mana yang 
paling memberikan kontribusi paling besar. Dengan mengetahui bentuk dukungan sosial yang paling memberikan kontribusi dalam menurunkan burnout, maka hasil penelitian ini dapat bermanfaat secara praktis kepada pimpinan program studi, para dosen untuk memberikan konseling yang tepat untuk mahasiswanya. Sedangkan manfaat dalam hal teoretis, menambah wawasan ke-ilmu-an dalam bidang psikologi Pendidikan dan kesehatan mental. Adapun hipotesis yang diajukan dalam penelitian ini adalah (1) appraisal support berperan signikan dalam menjelaskan burnout academic pada mahasiswa psikologi di Universitas " $X$ " Bandung (H1), (2) belonging support berperan signifikan dalam menjelaskan burnout academic pada mahasiswa psikologi di Univeristas " $\mathrm{X}$ " Bandung (H2). (3) tangible support berperan signifikan dalam menjelaskan burnout academic pada mahasiswa psikologi di Univeristas " $\mathrm{X}$ " Bandung (H3).

\section{Metode}

\section{Partisipan dan desain penelitian}

Penelitian ini menggunakan pendekatan kuantitatif, dengan menggunakan metode korelasional. Desain penelitian adalah studi cross sectional menggunakan kuesioner. Populasi pada penelitian sebanyak 612 orang. Pengumpulan data dalam penelitian ini menggunakan teknik sampling kuota pada mahasiswa Psikologi Program Studi Sarjana di Universitas " $X$ " Bandung selama jangka waktu tiga minggu yang dilakukan secara daring dan mendapatkan 327 responden.

\section{Prosedur dan pengukuran}

Penelitian ini menggunakan 2 alat ukur, yaitu MBI - SS yang disusun oleh Schaufeli (2002) untuk mengukur academic burnout dan ISEL-Shortened Version yang disusun oleh Cohen dkk. (2000) untuk mengukur dimensi dukungan sosial. Kedua alat ukur ini diterjemahkan oleh peneliti dan diuji ulang validitas dan reliabilitasnya. Hasil uji coba pada alat ukur MBI - SS didapatkan validitas dimensi emotional exhaustion nilai validitas $.51-.84$, dimensi cynisism nilai validitas $.73-.83$, dimensi personal efficacy nilai validitas $.48-.74$. Seluruh aitem dinyatakan valid. Nilai reliabilitas untuk dimensi emotional exhaustion adalah .85 yang termasuk kategori reliablitas tinggi. Nilai reliabilitas untuk dimensi cynisism adalah .78 yang termasuk kategori reliabilitas tinggi. Nilai reliabilitas untuk dimensi personal efficacy adalah .73 yang termasuk kategori reliablitas tinggi.

Pada alat ukur ISEL, didapatkan validitas dimensi appraisal support nilai validitas $.82-.87$, dimensi belonging support nilai validitas $.57-.73$, dimensi tangible support nilai validitas $.59-.70$. Satu aitem ditolak untuk dimensi appraisal support. Nilai reliabilitas dimensi appraisal support adalah .78 yang termasuk kategori reliablitas tinggi. Nilai reliabilitas untuk dimensi belonging support adalah .55 yang termasuk kategori reliablitas sedang. Nilai reliabilitas dimensi tangible support adalah .52 yang termasuk kategori reliablitas sedang. Perhitungan untuk analisis data dari masing-masing alat ukur dihitung dengan cara menjumlahkan tiap skor dari item-item yang valid. Teknik analisis data menggunakan uji analisis regresi linear berganda.

\section{Hasil}

Beberapa uji prasyarat dilakukan oleh peneliti sebelum dilakukan uji regresi dan hasilnya adalah sebagai berikut: 
- Uji normalitas, hasil pengujian normalitas data menggunakan uji Kolmogorov Smirnov menunjukkan data berdistribusi normal dengan $p=.053$.

- Uji linearitas menunjukkan hubungan antara variabel independen dan variabel dependen adalah linear dimana memiliki nilai $p$ tidak signifikan (appraisal support, $p=.609 ;$ belonging support, $p=$ .341 ; tangible support, $p=.378$ ).

- Uji multikolinearitas menunjukkan bahwa dari hasil pengujian setiap bentuk dukungan sosial tidak mengalami multikolinearitas, karena memiliki nilai Tolerance > 0.10 dan the variance inflation factor $(\mathrm{VIF})<10.00$, appraisal support dengan nilai $p=.647$; belonging support dengan nilai $p=.605$; tangible support dengan nilai $p=.678$.

- Uji heteroskedastistas menunjukkan hasil bahwa tidak adanya gejala heteroskedasitas sehingga dapat dilakukan uji regresi

Tabel 1. Uji Hipotesis Social Support dan Academic Burnout.

\begin{tabular}{lccccccc}
\hline Dimensi social support & $B$ & $S E$ & $t$ & $R^{2}$ & $p$ & $\beta$ & Keterangan \\
\hline Appraisal support & -1.42 & 0.54 & -2.63 & 0.12 & .009 & -0.16 & H1 diterima \\
Belonging support & -1.44 & 0.35 & -4.14 & 0.15 & .000 & -0.27 & H2 diterima \\
Tangible support & -0.37 & 0.35 & -1.04 & 0.08 & .300 & -0.06 & H3 ditolak \\
\hline
\end{tabular}

Keterangan. $B=$ koefisien regresi tidak tersatndarisasi, $S E=$ kesalahan standar, $R^{2}=$ koefisien determinasi, $p=$ nilai signifikansi, $\beta=$ koefisien regresi terstandarisasi; H1-H3 = Hipotesis 1-Hipotesis3.

Tabel 1 di atas menunjukkan bahwa dari hasil pengujian hipotesis yang dilakukan, hipotesis penelitian pertama dan hipotesis penelitian kedua diterima yang berarti adanya peran dari appraisal support dan belonging support terhadap academic burnout sedangkan hipotesis penelitian ketiga ditolak yang berarti tidak adanya kontribusi tangible support terhadap academic burnout. Partial correlation dapat dilihat dari nilai Beta masing-masing aspek dimana pada aspek appraisal support memiliki nilai -0.16, aspek belonging support -0.27, dan aspek tangible support sebesar -0.06. Hal ini menujukkan effect size dari aspek appraisal support memiliki kontribusi sebesar $16 \%$ dalam menurunkan academic burnout, aspek belonging support memiliki kontribusi sebesar $27 \%$ dalam menurunkan academic burnout, serta aspek tangible support memiliki kontribusi sebesar $6 \%$ dalam menurunkan academic burnout.

\section{Diskusi}

Berdasarkan pengujian hipotesis yang dilakukan dengan korelasi Product Moment 
diperoleh hasil bahwa $\mathrm{H} 1$ diterima untuk bentuk appraisal support dan belonging support; hal ini berarti bahwa kedua bentuk dukungan sosial memberikan peran terhadap academic burnout pada mahasiswa psikologi. Sedangkan untuk tangible support, H3 ditolak yang berarti bahwa bentuk tangible support tidak memberikan kontribusi terhadap academic burnout pada mahasiswa psikologi. Sedangkan peran ketiga bentuk dukungan sosial mendapatkan $R^{2}$ sebesar $0.2 \%$ dengan $p<.001$. Hal ini menunjukkan bahwa pengaruh bentuk dukungan sosial secara signifikan hanya sebesar $18 \%$ terhadap academic burnout. Berarti ada faktor-faktor lain yang mempengaruhi academic burnout pada mahasiswa psikologi.

Hal ini sejalan dengan penelitian yang dilakukan oleh Purba dkk. (2007) pada guru yang menyatakan bahwa semakin besar dukungan sosial yang diterima oleh guru mengurangi derajat burnout. Demikian juga penelitian yang dilakukan oleh Putri (2014) pada perawat di Rumah sakit di Bogor mendapatkan hasil bahwa dukungan sosial memberikan pengaruh yang kuat dalam menghadapi burnout. Hasil dari penelitian menunjukkan bahwa kedua bentuk dukungan sosial, yaitu belonging dan appraisal memberikan kontribusi terhadap academic burnout pada mahasiswa psikologi.

Belonging support memberikan kontribusi sebesar $15 \%$ dalam kaitan dengan academic burnout pada mahasiswa. Menurut Cohen dan Hoberman (dalam Cohen dkk., 2000) belonging support merupakan dukungan emosional dalam bentuk mengajak individu untuk tetap terlibat dalam kegiatan sehari-hari. Mahasiswa psikologi yang berada dalam kondisi academic burnout terbantu dengan dukungan dari teman-teman yang melibatkan mereka dalam mengikuti proses kuliah; dalam bentuk MEDIAPSI | 2021, Vol. 7, No. 1, 17-26 mengajak diskusi membahas materi-materi kuliah yang sulit, mendengarkan cerita. Mendengarkan dalam pengertian memberikan saran atau membuat penilaian. Dukungan emosional dimaknai dengan adanya seseorang yang selalu mendampingi dan menghargai apa yang di lakukan. Pada saat lingkungan memberikan kesempatan mahasiswa untuk terlibat dalam proses studi dan cerita-ceritanya didengarkan maka menurunkan tekanan emosi (emotional exhaustion) dan cynicism, yaitu ketidakpedulian atau sikap menjauh terhadap perkuliahan yang dijalani. Melalui proses interaksi dengan lingkungan teman, maka terjadi proses appraisal/penilaian terhadap situasi kuliah yang menekan akan berubah seiring dengan adanya belonging support.

Appraisal support memberikan kontribusi sebesar $12 \%$ dalam kaitan dengan academic burnout pada mahasiswa psikologi. Menurut Cohen dan Hoberman (dalam Cohen dkk., 2000) appraisal support merupakan dukungan dalam bentuk pemberian informasi-informasi, feedback, dan saran yang diberikan kepada individu yang dapat digunakannya untuk melakukan pengambilan keputusan dan coping terhadap permasalahan yang sedang dialaminya. Dukungan appraisal membantu mahasiswa untuk mendapatkan informasi penting yang dapat digunakan untuk melakukan penilaian ulang/appraisal atas situasi yang menekan sehingga coping menjadi efektif. Pada saat mahasiswa mengalami academic burnout, Schaufeli dkk. (2002) mengungkapkan bahwa kondisi ini mengacu pada perasaan lelah karena tuntutan studi, memiliki sikap sinis terhadap tugas-tugas perkuliahan, dan perasaan tidak kompeten sebagai mahasiswa. Perasaan lelah secara emosi akan menutup semua informasi yang diperlukan untuk memahami situasi secara obyektif sehingga coping yang dilakukan menjadi tidak efektif. 
Dengan demikian, appraisal support menolong mahasiswa untuk memiliki perspektif yang lebih luas terhadap tekanan studi yang dialami. Persepektif yang luas dengan pemberian informasi akan menolong mahasiswa untuk melakukan coping secara efektif.

Tangible support tidak memberikan kontribusi terkait dengan academic burnout pada mahasiswa. Bagi mahasiswa psikologi, pemberian dukungan dalam bentuk dukungan langsung yang diberikan dalam rupa material seperti jasa, waktu, bantuan, tumpangan transportasi, atau uang untuk membantu menghadapi permasalahan yang sifatnya praktis yang agar individu yang sedang menghadapi permasalahan memiliki waktu untuk beristirahat ternyata tidak memberikan kontribusi.

Dari hasil penelitian ini, bentuk dukungan social yang paling berperan adalah belonging, selanjutnya adalah appraisal. Sedangkan tangible support tidak memberikan kontribusi. Berarti ada dua bentuk dukungan sosial yang dipersepsi dapat menurunkan academic burnout. Pengalaman belajar sebagai mahasiswa psikologi dengan materi-materi yang terkait dengan memahami individu dengan permasalahannya membuat mahasiswa mempersepsi bahwa pada saat tekanan dalam proses studi menjadi kuat sampai memunculkan academic burnout, maka yang dibutuhkan adalah dukungan sosial dalam bentuk memberikan pengertian yang mendalam secara emosional dan pemberian informasi-informasi yang akurat untuk mengurangi tekanan dalam proses studi.

Dari hasil analisis data penelitian diatas, maka dapat disimpulkan bahwa bentuk dukungan sosial yang paling berperan dalam academic burnout adalah belonging dan appraisal. Sedangkan tangible support tidak memberikan peran yang cukup dalam academic burnout.

Penelitian ini memberikan informasi dan hasil tambahan berupa sumbangan efektif sebesar $15 \%$ dan $12 \%$, sedangkan sisanya sebesar $85 \%$ dipengaruhi oleh faktor-faktor lainnya, seperti karakteristik perkuliahan, persepsi terhadap proses studi, sebagai faktor situasional serta karakteristik individu lainnya (trait, konsep diri, locus of control). Keterbatasan dalam penelitian ini adalah tidak mengukur derajat academic burnout yang dihayati oleh mahasiswa. Dengan mengetahui derajat academic burnout yang dihayati oleh mahasiswa, akan didapatkan data yang lebih spesifik mengenai bentuk dukungan sosial mana yang lebih berperan.

Berdasarkan hasil penelitian yang diperoleh, maka dapat diajukan beberapa saran yang dapat dijadikan masukkan sebagai bahan pertimbangan. Bagi mahasiswa psikologi, perlu memiliki pengenalan diri secara mendalam mengenai trait, locus of control, self efficacy serta kemampuan mengenali, mengelola stress secara efektif. Belajar meluangkan waktu untuk membina relasi yang mendalam dengan orang-orang yang dapat memberikan dukungan dalam proses studi. Bagi dosen pengajar, secara khusus dosen wali mahasiswa psikologi, perlu menyediakan waktu yang rutin untuk memberikan konseling kepada mahasiswa walinya selama proses studi dan memperhatikan situasi pembelajaran di kelas. Bagi peneliti selanjutnya, peneliti lainnya yang tertarik untuk meneliti dengan tema yang sama, diharapkan dapat mengukur derajat academic burnout yang dikaitkan dengan bentuk dukungan sosial. Sedangkan untuk penelitian lanjutan dengan tema yang sama dapat menggunakan metode kualitatif. 
Penelitian serupa bisa dilakukan kembali pada sampel mahasiswa yang studi pada program, seperti jurusan kedokteran umum, kedokteran gigi, keperawatan, kesejahteraan sosial, konseling, pendidikan guru, teologia, dan sebagainya. Selain itu, mengembangkan penelitian yang menjangkau faktor-faktor lain yang mempengaruhi academic burnout pada mahasiswa, secara khusus mengenai trait, locus of control, dan self efficacy.

\section{Kesimpulan}

Berdasarkan hasil penelitian terbukti bahwa dukungan sosial sangat penting dalam menurunkan academic burnout terutama dukungan sosial dalam bentuk appraisal support dan belonging support. Penting bagi mahasiswa untuk mendapatkan dukungan sosial agar proses perkuliahan yang dijalani tidak terkendala oleh berbagai macam tekanan. Selain itu, mahasiswa harus proaktif dalam mencari dukungan sosial sesuai kebutuhan.

\section{Daftar Pustaka}

Almeida, G. D. C., Souza, H. R. D., Almeida, P. C. D., Almeida, B. D. C., \& Almeida, G. H. (2016). The prevalence of burnout syndrome in medical students. Archives of Clinical Psychiatry (São Paulo), 43(1), 6-10. https://doi.org/10.1590/010160830000000072

Baron, R. A., \& Greenberg, J. (2008). Behaviour in organization: Understanding and managing the human side at work ( $3^{\text {rd }}$ ed.) Allyn \& Bacon.

Bedewy, D., \& Gabriel, A. (2015). Examining perceptions of academic stress and its sources among university students: The perception of academic stress scale. Journal of Health Psychology Open, 2(2), 1-9. https://doi.org/10.1177/205510291559 6714

Burr, J., \& Dallaghan, G. L. B. (2019). The relationship of emotions and burnout to medical students' academic performance. Teaching and Learning in Medicine, 31(5), 479-486. https://doi.org/10.1080/10401334.2019 .1613237

Chambel, M. J., \& Curral, L. (2005). Stress in academic life: Work characteristics as predictors of student well-being and performance. Applied

Psychology, 54(1), $135-147$. https://doi.org/10.1111/j.14640597.2005.00200.x

Cohen, S., Underwood, L. G., \& Gottlieb, B. H. (Eds.). (2000). Social support measurement and intervention: $A$ guide for health and social scientists. Oxford University Press.

Cole, M. S., Feild, H. S., \& Harris, S. G. (2004). Student learning motivation and psychological hardiness: Interactive effects on students' reactions to a management class. Academy of Management Learning \& Education, 3(1), 64-85. https://doi.org/10.5465/amle.2004.124 36819

Das, P. P. P., \& Sahoo, R. (2012). Stress and depression among post-graduate students. International Journal of Scientific and Research Publication, 2(7), 1-5. http://www.ijsrp.org/research_paper_j ul2012/rp52.html

de Vibe, M., Solhaug, I., Tyssen, R., Friborg, O., Rosenvinge, J. H., Sørlie, T., \& Bjørndal, A. (2013). Mindfulness training for stress management: A randomised controlled study of medical and psychology students. BMC Medical Education, 
13(1), 1-11. https://doi.org/10.1186/1472-6920-13107

Gold, Y., \& Roth, R. A. (1993). Teachers managing stress and preventing burnout: The professional health solution. The Flamer Press.

Gulo, W. (2010). Metodologi penelitian. Grasindo.

Jayanthi, P., Thirunavukarasu, M., \& Rajkumar, R. (2015). Academic stres and depression among adolescents: A cross-sectional study. Indian Pediatrics, 52(3), 217-219. https://doi.org/10.1007/s13312-0150609-y

Jiménez-Ortiz, J. L., Islas-Valle, R. M., Jiménez-Ortiz, J. D., Pérez-Lizárraga, E., Hernández-García, M. E., \& González-Salazar, F. (2019). Emotional exhaustion, burnout, and perceived stress in dental students. Journal of International Medical Research,47(9), 4251-4259. https://doi.org/10.1177/030006051985 9145

Khairani, Y., \& Ifdil, I. (2015). Konsep burnout pada mahasiswa bimbingan dan konseling. Ejurnal Unp, 4(4), 208214.

https://doi.org/10.24036/02015446474 $-0-00$

Kim, B., Jee, S., Lee, J., An, S., \& Lee, S. M. (2017). Relationships between social support and student burnout: A meta-analytic approach. Stress and Health, 34(1), 127134. https://doi.org/10.1002/smi.2771

Lin, S. H., \& Huang, Y. C. (2014). Life stress and academic burnout. Active Learning in Higher Education, 15(1), 77-90. https://doi.org/10.1177/146978741351 4651

Marshall, L. L., Allison, A., Nykamp, D., \& Lanke, S. (2008). Perceived stress and quality of life among doctor of pharmacy students. American Journal of Pharmaceutical Education, 72(6), 1-8.

https://doi.org/10.5688\%2Faj7206137

Maslach, C. (2003). Burnout: The cost of caring. Malor Books.

Maslach, C., \& Leiter, M. P. (2016). Understanding the burnout experience: Recent research and its implications for psychiatry. World Psychiatry, 15(2), 103-111. https://doi.org/10.1002/wps.20311

Muna, N. R. (2013). Efektivitas teknik self regulation learning dalam mereduksi tingkat kejenuhan belajar siswa. Jurnal Holistik, 14(2), 57-78. http://doi.org/10.24235/holistik.v14i2. 450

Purba, J., Yulianto, A., Widyanti, E., Esa, D. F. P. U. I., \& Esa, M. F. P. U. I. (2007). Pengaruh dukungan sosial terhadap burnout pada guru. Jurnal Psikologi, 5(1), 77-87. https://digilib.esaunggul.ac.id/public/U EU-Journal-4982-johanaP.aries.pdf

Putri, D. (2014). Analisa Pengaruh dukungan sosial terhadap burnout pada perawat (Skripsi, Universitas Diponegoro). http://eprints.undip.ac.id/43596/1/01_P UTRI.pdf

Rafidah, K., Azizah, A., Norzaidi, M. D., Chong, S. C., Salwani, M. I., \& Noraini, I. (2009). Stress and academic performance: Empirical evidence from university students. Academy of Educational Leadership Journal, 13(1), 37-51. 
https://www.researchgate.net/publicati on/299615555_STRESS_AND_ACA DEMIC_PERFORMANCE_EMPIRIC AL_EVIDENCE_FROM_UNIVERSI TY_STUDENTS

Rahmati, Z. (2015). The study of academic burnout in students with high and low level of self-efficacy. Procedia-Social and Behavioral Sciences, 171, 49-55. https://doi.org/10.1016/j.sbspro.2015.0 1.087

Rana, H. (2016). Impact of student's burnout on academic performance / achievement. Pollster Journal of Academic Research, 3(02), 159-174. http://www.pollsterpub.com/images/3. 2.4.pdf

Schaufeli, W. (2002). Burnout and engagement in university students: A cross-national study. Journal of CrossCultural Psychology, 33(5), 464-481. https://doi.org/10.1177/002202210203 3005003

Sutoyo, D., Kadarsah, R. K., \& Fuadi, I. (2018). Sindrom burnout pada peserta program pendidikan dokter spesialis anestesiologi dan terapi intensif Fakultas Kedokteran Universitas Padjadjaran. Jurnal Anestesi Perioperatif, 6(3), 153-161. https://doi.org/10.15851/jap.v6n3.1360

Waqas, A., Khan, S., Sharif, W., \& Ali, A. (2014). Association of academic stressors with sleep disturbances in medical students: Is psychological stress a mediator? PeerJ PrePrints. https://doi.org/10.7287/peerj.preprints. 706v1

Wilder, S. (2014). Effects of parental involvement on academic achievement: A metasynthesis. Educational Review, 66(3), 377-397. https://doi.org/10.1080/00131911.2013 .780009

Yang, H. (2004). Factors afecting student burnout and academic achievement in multiple enrolment programs in taiwan's techincal-vocational colleges. International Journal of Educational Development, 24(3), 283-301. https://doi.org/10.1016/j.ijedudev.2003 